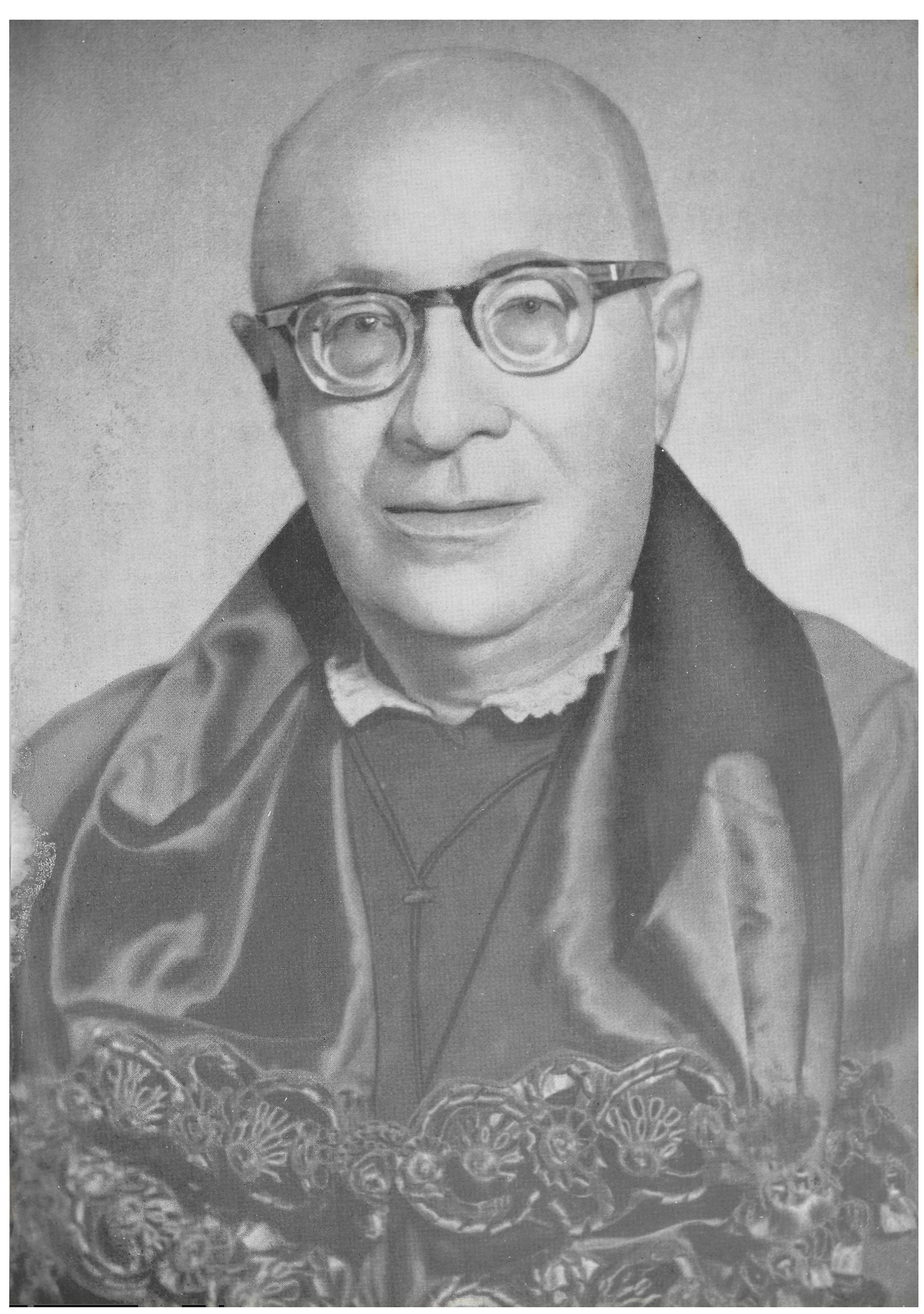


IN MEMORIAM.

\section{Braz de Sousa Arruda.}

A 24 de junho de 1963, faleceu, com 68 anos de idade, o Prof. Braz de Sousa Arruda. Era dos mais conceituados mestres de direito internacional do nosso país. Foi durante cerca de quarenta anos quem se incumbiu, com desvêlo e carinho, do ensino dêsse direito na Universidade de São Paulo.

Nasceu, aos 3 de fevereiro de 1895, na cidade de Campinas, onde seu pai, o ilustre Professor JoÃo Arruda, era então Juiz de Direito. Depois dos estudos secundários feitos em Ribeirão Preto e na cidade natal, cursou esta Faculdade onde colou grau em 1916.

O brilho e talento com que se dedicou aos estudos testemunharam intenso pendor para a vida universitária. Em 1919, já como livre docente, se apresentava a concurso para as cadeiras de Direito Internacional Público, Direito Internacional Privado e Direito Constitucional. Aprovado e classificado em primeiro lugar, fixou-se, por decreto de 1925, na Cadeira de Direito Internacional Público, que, desde então, passou a reger. Era o decano dos professôres universitários brasileiros.

Apesar de convocado com freqüência para funções públicas estranhas à vida universitária, que por vêzes chegou transitòriamente a exercer, preferia dedicar-se à ciência de sua predileção e à Escola, que governou com eficiência durante largo período.

Foi na qualidade de diretor da Faculdade de Direito e de membro do Conselho da Universidade de São Paulo 
que impulsionou o intercâmbio científico com o estrangeiro, e, no que diz respeito mais de perto aos cultores do direito internacional, procurou vinculá-los mùtuamente a laços estáveis de compreensão e de trabalho construtivo e fecundo.

Presidiu a Comissão Orgnizadora do "II Congresso Hispano-Luso-Americano de Direito Internacional", celebrado nesta Capital de 2 a 12 de outubro de 1953, e na Escola da qual era dirigente. Foi, a seguir, presidente do Instituto e membro de seu Conselho Diretor.

Deixou Braz de Sousa Arruda obra variada e numerosa. Nela se distinguem duas partes principais. A primeira concerne a temas educacionais e pedagógicos, tais como $O$ problema universitário, São Paulo, 1925, Ação social do Estado sôbre a instrução pública (Revista da Faculdade de Direito, vol. 21, 1913), O estudo do Direito no Brasil (Revista da Faculdade de Direito, vol. 32, 1936), A Faculdade de Direito, a Universidade e os problemas do ensino (Revista da Faculdade de Direito, vol. 41, 1946).

A segunda parte diz respeito a temas de natureza juridica. Escreveu sôbre direito público em geral, sôbre finanças e economia: Diferença entre direito administrativo e ciência da administração, Estado de sítio e eleições (Revista de Direito, Rio de Janeiro, vol. 49, 1918), Deve o salário do operário ser proporcional ḋ renda da terra $e$ ao proveito do capital?, Prelecões de Ciência das Finanças, (São Paulo, Linotécnica, 1937). Todavia, não há negar, a decisiva contribuição de Braz de Sousa Arruda foi em relação ao direito das gentes, que, iniciada desde antes da primeira conflagração mundial, não cessou jamais de se ampliar e renovar.

Quanto ao direito internacional, a obra de BRAZ DE Sousa Arruda abrange, por sua vez, dois setores distintos. 0 primeiro é atinente aos cursos regulares que lhe competia professar. Daí ter publicado já em 1927, nesta Revista as Preleções de Direito Internacional Público. Com- 
preendem elas quarenta e dois pontos. Versam assuntos que se estendem desde Noção e Fundamento até $A$ América $e$ o Direito Internacional e Órgãos Deliberativos e Judiciários. Em 1938, a mesma Revista inclui a Estrutura do Direito Internacional (vol. 34). Trata-se de preleções feitas no Curso de Doutorado, que focalizam com mais amplitude temas estudados no Curso anterior bem como novos assuntos. Estas preleções foram reeditadas no volume número 36 da Revista e concernente ao ano de 1941.

$O$ segundo setor do direito das gentes se refere a temas avulsos, tais como Danos por operações de guerra (Revista da Faculdade de Direito, vol. 22, 1914-1925), Progresso e futuro do direito internacional (vol. 23, 1926 e 1927), A Mulher na Diplomacia (vol. 27, 1931), Crueldade nas guerras (vol. 37, 1942), Ruy Barbosa e o direito das gentes (vol. 40, 1945). $O$ direito internacional $e$ os progressos técnicos (vol. 54, 1959).

O último congresso a que Braz de Sousa Arruda compareceu foram as "Jornadas de Derecho Internacional", promovidas pela Associação Argentina de Derecho Internacional e realizadas em Buenos Aires de 10 a 16 de setembro de 1960.

Estava ùltimamente escrevendo um novo Curso de Direito Internacional, ampliação e atualização dos anteriores. A morte impediu Braz de Sousa Arruda de ultimá-lo, cortando bruscamente a trajetória de uma vida que foi, a rigor inteiramente consagrada ao ensino e à ciência. 